\title{
Microbiological Quality of Raw Goat Milk in Bogor, Indonesia
}

\author{
E. Taufik ${ }^{a, \#, *}$, G. Hildebrandt' ${ }^{b}$ J. N. Kleer ${ }^{b}$, T. I. Wirjantoroc ${ }^{c}$ K. Kreausukon ${ }^{d}$ K. H. Zessin ${ }^{\mathrm{e}}$, M. P. O. \\ Baumann $^{\mathrm{e}}$, \& F. H. Pasaribu ${ }^{\mathrm{f}, \#}$ \\ ${ }^{a}$ Department of Animal Production and Technology, Faculty of Animal Science, Bogor Agricultural University \\ ' Institute of Food Hygiene, Faculty of Veterinary Medicine, Freie Universität Berlin \\ Königsweg 6914163 Berlin, Germany \\ 'Department of Food Science and Technology, Faculty of Agro-Industry, Chiang Mai University \\ 155 Moo 2 Tambon Mae Hia, Muang, Chiangmai 50100 Thailand \\ dVeterinary Public Health Center for Asia Pacific, Chiang Mai University \\ Mae Hia, Muang, Chiang Mai 50100 Thailand \\ ePostgraduate Studies of International Animal Health, Faculty of Veterinary Medicine, Freie Universität Berlin \\ Königsweg 6714163 Berlin, Germany \\ fDepartment of Animal Diseases and Veterinary Public Health, Faculty of Veterinary Medicine, \\ Bogor Agricultural University \\ "Jln. Agatis Kampus IPB Darmaga, Bogor 16680 \\ (Received 29-10-2010; accepted 28-04-2011)
}

\begin{abstract}
ABSTRAK
Investigasi terhadap kualitas mikrobiologis susu kambing mentah dengan menggunakan angka lempeng total bakteri (ALTB), koliform, Staphylococcus koagulase positif (CPS) dan Staphylococcus koagulase negatif (CNS) sebagai bakteri indikator, telah dilaksanakan. Sepuluh faktor resiko yang berpotensi terkait dengan adanya bakteri indikator tersebut juga telah dievaluasi. Hasil penelitian menunjukkan bahwa nilai median dari jumlah bakteri indikator dalam sampel susu asal ambing dan susu kandang untuk masing-masing bakteri indikator, yaitu ALTB, koliform, CPS, dan CNS adalah 3,$74 ; 0,70 ; 1,70 ;$ dan 2,52 log cfu/ml untuk susu ambing dan 5,69; 2,98; 3,66; dan 3,32 log cfu/ $\mathrm{ml}$ untuk susu kandang. Nilai median semua bakteri indikator dari sampel susu ambing tidak ada yang melebihi batas maksimum standar yang berlaku. Namun demikian, untuk sampel susu kandang, hanya jumlah ALTB saja yang memenuhi standar yang ada. Prevalensi total bakteri indikator, yaitu koliform, CPS, dan CNS dalam sampel susu ambing masing-masing adalah 46,3\%; 37,7\%; dan $66,0 \%$, sedangkan dari sampel susu kandang adalah $86,7 \%$; 76,7\%; dan 86,7\%. Kambing dari bangsa peranakan Saanen, paritas ke- 5 dan ambing yang radang telah terbukti sebagai faktor resiko. Data di atas menunjukkan bahwa praktik higiene yang baik di peternakan masih belum optimal dilaksanakan. Kontaminasi bakteri pada susu dapat dikontrol dengan mengendalikan faktor-faktor resiko yang telah teridentifikasi.
\end{abstract}

Kata kunci: susu kambing, ALTB, koliform, CPS, CNS, faktor resiko

\section{ABSTRACT}

Milk samples were investigated for counts and prevalence of indicator bacteria, which were TPC, coliforms, coagulase positive Staphylococci (CPS), and coagulase negative Staphylococci (CNS). Ten potential risk factors were also evaluated in relation to the prevalence of indicator bacteria. The results showed that the median values of indicator bacterial counts from overall udder-half milk samples were 3.74, 0.70, 1.70, and $2.52 \mathrm{log} \mathrm{cfu} / \mathrm{ml}$ and from bulk milk samples were $5.69,2.98,3.66$ and $3.32 \log \mathrm{cfu} / \mathrm{ml}$ for TPC, coliforms, CPS, and CNS, respectively. None of the median values of overall udder-half milk samples exceeded the maximum limit of the standards for all indicator bacteria. However, in the bulk milk samples only the median value of TPC below the maximum limit of the standards. Overall prevalence of coliforms, CPS and CNS from udder-half milk samples were $46.3 \%, 37.7 \%$, and $66.0 \%$, respectively, and from bulk milk samples were $86.7 \%, 76.7 \%$, and $86.7 \%$, respectively. Saanen crossbreed, fifth parity and udders with inflammation were found to be risk factors. This study results indicated that the hygienic practices in the dairy goat farms are still need

\footnotetext{
* Corresponding author:
}

epitaufik@ipb.ac.id 


\section{to be increased. To increase the hygienic level of the milk, the identified significant risk factors must} be controlled.

Key words: goat milk, TPC, coliforms, CPS, CNS, risk factor

\section{INTRODUCTION}

According to FAO (2010), Indonesia was ranked as the $7^{\text {th }}$ in the list of global goat milk production and ranked as the $1^{\text {st }}$ in the Southeast Asia region in 2009. The goat milk production in Indonesia in that year was 238,000 ton. Bangladesh was in the $1^{\text {st }}$ position for producing goat milk globally as it reached 2,168,000 ton in the same year.

Galal (2005) reported that developing countries harbour $96 \%$ of the world goat population, but only $60 \%$ of the breeds. According to compositional differences between the milk from cows, goats and sheep, the quality standards for the milk from small ruminant animals should be adjusted and evaluated based on the individual milk source (Morgan et al., 2003; Zweifel et al., 2005).

Most of the reports concerning the microbiological characteristics of goat milk were dealt only with investigation on the prevalence of target pathogenic organisms, SCC and microbial quality of the milk (McDougall et al., 2002; Foschino et al., 2002; Raynal-Ljutovac et al., 2005; Wakwoya et al., 2006; Contreras et al., 2007; Leitner et al., 2007; Hall \& Rycroft, 2007, Koop et al., 2010; McDougall et al., 2010).

Whereas reports on the evaluation of different factors concerning farm management and milking practices as well as other predisposing factors from goat condition in association with microbial quality and the prevalence of pathogenic bacteria in goat milk were very limited (Ndegwa et al., 2001; Zweifel et al., 2005; Kyozaire et al., 2005; Moroni et al. 2005; Lilenbaum et al., 2008; Megersa et al. 2010; Oliviera et al., in press).

In Indonesia, so far raw goat milk has less attention in terms of quality and safety control from farmer organizations and/or government institutions than those for cow milk and milk products. Whereas the most of the consumers are prefer to drink raw goat milk due to their belief in its benefit as a health promoting or even disease-relief agent. This condition is in line with the report from Oliver et al. (2005), they stated that although numerous studies have documented that foodborne pathogens of public health significance have been isolated from bulk tank milk and are capable of causing disease in humans, people continue to consume raw milk.

Staphylococcus spp. can be found widely distributed in animals, and it is a contagious pathogen that can be transmitted from doe to doe during unhygienic milking procedures. Staphylococcus spp. are the main etiological agents of small ruminant's intramammary infections (IMI) (Stuhr \& Aulrich, 2010), the more frequent isolates being Staphylococcus aureus (coagulase-positive staphy- lococci [CPS]) in clinical cases and coagulase-negative staphylococci (CNS) in subclinical IMI (Bergonier et al., 2003).

High prevalence of CPS such as S. aureus, or CNS can be of veterinary public health concern (Silanikove et al., 2010). Both groups of bacteria are important zoonotic bacterial pathogens, which can also be transmitted to humans through goats' raw milk and cause food poisoning associated with enterotoxin production (Wakwoya et al., 2006). Gonzalo et al. (2002) and Koop et al. (2010) also reported that subclinical mastitis in goats decrease the milk yield and especially CNS can changed the milk composition especially its curd yield Leitner et al. (2004).

Investigation on the microbiological quality such as Total Plate Count (TPC), coliforms as quality and safety indicators, and the presence of pathogenic bacteria of goat milk together with some risk factors affecting these microorganisms in Indonesia was very rare. Therefore the objective of this study were to investigate the microbiological quality of raw goat milk by using several indicator bacteria and to evaluate the potential risk factors associated with them in dairy goat farms in the Bogor District, West Java Province, Indonesia.

\section{MATERIALS AND METHODS}

\section{Study Design and Location}

This study was a cross sectional survey to investigate the microbiological quality and the association of possible risk factors with the microbiological status of raw goat milk. Three dairy goat farms with herd sizes of 600,400, and 200, respectively, in the Bogor District, West Java Province, Indonesia were conveniently selected as sampling sites.

\section{Questionnaire}

Questionnaires were used for collecting information regarding possible risk factors, which reflected udder, teat and the goat's general condition. The questionnaires were completed by the investigator during the farm visits.

\section{Type of Sample}

The main milk sample that was used in this study was individual udder half (left and right udder) milk of lactating goats, which was collected at the time of sampling visits. Two parallel bulk milk samples were taken from each farm at every visiting time as an additional sample. Ten milliliters of milk was collected for each sample, either from udder-half or bulk milk. 


\section{Laboratory Investigation Standard Procedures}

General rules for the preparation of the initial suspension and decimal dilutions were based on ISO 6887-1 (1999). US FDA-BAM (United States Food and Drug Administration-Bacteriological Analytical Manual) online for analysis of Aerobic Plate Count (FDA, 2001) was followed for conventional culture of TPC, whereas for the total coliforms count, the $3 \mathrm{M}^{\mathrm{TM}}$ Petrifilm ${ }^{\mathrm{TM}}$ interpretation guide for the total coliforms count (Petrifilm ${ }^{\mathrm{TM}}$, 2008) was followed. To investigate the presence and enumeration of coagulase positive and negative staphylococci in the sample, the ISO 6888-1 (1999) standard technique by using Baird Parker agar medium was used. The California Mastitis Test (CMT) was done according to Shearer \& Harris (2003).

\section{Sample Size Determination}

The Win Episcope ${ }^{\circledR}$ Version 2.0 (1998) program was used to determine sample size based on estimate prevalence. As the most prevalent IMI causing agent according to many scientific reports, the prevalence of CNS in goat milk was used as the expected prevalence. Since no report was found from Indonesia regarding CNS prevalence in goat milk, the prevalence of $25 \%$ of CNS reported by Bergonier et al. (2003) was used. At a 95\% level of confidence and 5\% accepted error, the sample size of 288 was obtained and then it was rounded up to 300 samples.

\section{Sampling Strategy and Evaluation of Potential Risk Factors}

The sample size was distributed to all farms equally, therefore from each farm 100 udder-half milk samples (from 50 different individual lactating goats) were collected. The apparently healthy lactating goats were selected conveniently in a studied farm during a visiting time. Each lactating goat was marked after milk sampling to avoid repetition in the sample collection. Observation of the general condition of the selected dairy herd, including examination of variation in teat and udder conformation, udder cleanliness and any abnormalities of the individual goat was recorded. Approximately $10 \mathrm{ml}$ of pre-milking milk samples were collected into sterile bottles from each udder half (left and right). Milk samples were directly kept at $\leq 4^{\circ} \mathrm{C}$ and transported in an icebox to the laboratory for microbiological analysis within 3 hours. The milking process was done by the farmer/milker, teat disinfection was carried out prior to the milk sampling using alcohol and forestripping was done before the main sample collection.

CMT was done by mixing $3 \mathrm{ml}$ of milk sample with $3 \mathrm{ml}$ of CMT reagent (provided by Faculty of Veterinary Medicine, CMU) in the CMT paddle. By gently rocking the CMT plate, the sample and reagent were carefully mixed and the result was observed within around 20 seconds. The CMT scores were 0 , trace, $+1,+2$, and +3 (Shearer \& Harris, 2003). For determining the status of udder inflammation, the score of CMT was further classified into two categories: negative and positive. The negative score was represented by CMT scores of 0 and "trace" and the positive score (indicator of subclinical mastitis/intramammary infection) by CMT scores of +1 , +2 and +3 (Wakwoya et al., 2006).

There were 10 potential risk factors examined in this study, some of them were subjectively scored by the investigator based on an adoption from the available scoring standard for dairy cow. The potential risk factors were breed of animal (three breeds were found in the field during investigation i.e. Ettawa crossbred, Saanen crossbred and Jawarandu), parity number (first to fifth), stage of lactation (first to third), udder symmetry (yes or no), score of udder hygiene (Ruegg, 2002), score of teat end condition (Mein et al., 2001), score of teat skin condition (Goldberg et al., 1994), teat shape condition (normal to general dilated), udder inflammation status (yes or no), and milk appearance (normal or abnormal).

\section{Statistical Analysis}

Descriptive statistics were used to describe enumeration and prevalence data. Chi-square univariate analysis was performed to evaluate the impact of each potential risk factor (derived from the questionnaire responses) to the pathogenic outcomes (present or not present) in samples. McNemar Chi-square test was used to compare the true proportion of positive results among two testing methods, whilst Cohen's kappa coefficient was used to evaluate the agreement between two test results. The multiple logistic regression model was carried out to evaluate the impacts of particular risk factors without interaction of each factors. Mann-Whitney U test or Kruskall-Wallis one way ANOVA were used to evaluate statistical significance in bacterial population among evaluated variables (Dawson \& Trapp, 2004).

\section{RESULTS AND DISCUSSION}

The median values of indicator bacterial counts from overall udder-half milk samples were 3.74, 0.70, 1.70, and $2.52 \mathrm{log} \mathrm{cfu} / \mathrm{ml}$ and from bulk milk samples were $5.69,2.98,3.66$, and $3.32 \mathrm{log} \mathrm{cfu} / \mathrm{ml}$ for TPC, coliforms, CPS and CNS, respectively (Table 1). The indicator bacterial counts from udder-half milk samples were significantly different $(\mathrm{P}<0.05)$ among farms, except for the CPS count, whereas from bulk milk samples, it was only the coliforms count that was observed to have statistically significant difference among farms. None of the median values of overall udder-half milk samples exceeded the maximum limit of available microbiological standards for TPC, coliforms and Staphylococcus aureus (for the Indonesian standard, since no special standard for goat milk available yet, standard for cow fresh milk was used as a comparison), however the samples had maximum values which exceeded the maximum limits within those standards. In bulk milk samples, it was only the median value of TPC that was below the maximum limit of standards. All indicator bacteria had maximum values beyond the maximum limits (Table 1 ).

Overall prevalence of coliforms, CPS and CNS from udder-half milk samples were $46.3 \%, 37.7 \%$, and $66.0 \%$, respectively (Table 2 ), and from bulk milk samples were 
$86.7 \%, 76.7 \%$, and $86.7 \%$, respectively. Results of this study showed that based on median values of indicator bacteria (Table 1), the microbiological quality of raw goat milk from udder-half milk samples complied with the available standards, whereas for the samples from bulk milk do not complied with the standards except for TPC. Prevalence of all indicator bacteria was relatively higher compared to the majority of other study results from other countries (Table 2).

The results of the evaluation of several potential risk factors in its association with the presence of indicator bacteria in the samples show that some of those potential risk factors could be considered to be risk factors, which significantly increased the risk of presence of each indicator bacteria i.e. Saanen crossbreed for coliforms, parity for CPS and udder inflammation for CPS (Table 3).

The data in Table 3 shows that the breed of goats was only significantly associated with the presence of coliforms in the samples. Saanen crossbreed had a significantly higher chance of coliforms contamination $(\mathrm{OR}=3.942, \mathrm{P}=0.000,95 \% \mathrm{CI}=2.348,6.618)$ than other breeds. It was likely to be associated with low resistance and adaptability of Saanen crossbreed to the environ- ment condition as compared to two others breeds which are local and tropical breed. A significant association of the parity factor with the presence of indicator bacteria was observed only in CPS. Further analysis by logistic regression test showed that only goats in fifth parity had a significantly positive association and higher risk of having CPS in the samples $(\mathrm{OR}=6.033, \mathrm{P}=0.050,95 \% \mathrm{CI}=$ 0.999, 36.455) (Table 3).

This result was also comparable to some previous reports, i.e. Boscos et al. (1996), who also found that no parity differences in the prevalence of type of bacteria isolated, but the proportion of positive samples was significantly higher in multiparous than in primiparous Saanen goats; Sanchez et al. (1999) who reported that prevalence of IMI (which was mostly caused by Staphylococcus spp. $[\mathrm{P}=70 \%])$ increased with the age of the goats, and they also found positive statistical association between subclinical intramammary infection and goats in greater than fifth parity $(\mathrm{PR}=1.80 ; 95 \% \mathrm{CI}=1.21$, 2.68); McDougall et al. (2001) reported that significant association in infection prevalence was found between goats older than 4 years and less than 4 years old and Moroni et al. (2005) who reported that goats in third and fourth parities had significantly more infection than

Table 1. Overall bacterial count from udder-half milk $(n=300)$ and bulk milk $(n=30)$ samples compared to the maximum limits of available standards

\begin{tabular}{|c|c|c|c|c|}
\hline \multirow{2}{*}{ Selected statistical value } & \multicolumn{4}{|c|}{ Bacterial count $(\log \mathrm{cfu} / \mathrm{ml})$} \\
\hline & Total plate count & CPS & Coliforms & $\mathrm{CNS}$ \\
\hline Median & $3.74(5.69)^{*}$ & $1.70(3.66)$ & $0.70(2.98)$ & $2.52(3.32)$ \\
\hline $\begin{array}{l}\text { Indonesian National Standard for Fresh Milk } \\
\text { (SNI 01-3141-1998) } \\
\text { (for comparison) }\end{array}$ & 6.00 & $\begin{array}{c}2.00 \\
(\text { for S. aureus })^{* *}\end{array}$ & 1.30 & - \\
\hline $\begin{array}{l}\text { EU Council Directive 92/46/EEC (raw goat and } \\
\text { sheep milk) (EC, 1992) }\end{array}$ & 5.70 & $\begin{array}{c}3.30 \\
\text { (for S. aureus) }\end{array}$ & 2.00 & - \\
\hline $\begin{array}{l}\text { German "Milchverordnung" of "raw } \\
\text { goat/sheep milk" for making raw based milk } \\
\text { products (BGBl, 2004) }\end{array}$ & 5.70 & $\begin{array}{c}3.30 \\
(\text { for S. aureus })^{* *}\end{array}$ & $\begin{array}{l}2.00 \text { (“Vorzugs- } \\
\text { milch"/special } \\
\text { raw milk) }\end{array}$ & - \\
\hline Minimum & $0.70(3.74)$ & $1.70(1.70)$ & $0.70(0.70)$ & $1.70(1.70)$ \\
\hline Maximum & $6.96(7.50)$ & $6.18(5.65)$ & $5.99(4.45)$ & $6.41(5.54)$ \\
\hline
\end{tabular}

Note: * Numbers in parentheses are for bulk milk samples; ** S. aureus is the most dominant species in CPS group of bacteria, in this case the CPS count was compared to $S$. aureus standard; $C P S=$ coagulase-positive Staphylococci; $C N S=$ coagulase-negative Staphylococci.

Table 2. Overall prevalence of indicator bacterial from udder-half milk samples and its comparison with prevalence from other study results

\begin{tabular}{cll}
\hline Indicator bacteria & Overall prevalence & \multicolumn{1}{c}{ Prevalence from other studies } \\
\hline Coliforms & $46.30 \%$ & $\cdot 12.0 \%$, UK (Little \& de Luvois, (1999) \\
CPS & $37.70 \%$ & $\cdot 18.5 \%$, Greece (Boscos et al., 1996) \\
& & $\cdot 45.34 \%$, Pakistan (Ali et al., 2010) \\
CNS & $66.00 \%$ & $\cdot 66.7 \%$, USA (McDougall et al., 2002) \\
& & $\cdot 9.6 \%$, Ethiopia (Wakwoya et al., 2006) \\
& $\cdot 17.9 \%$, Israel (Leitner et al., 2007) \\
& $\cdot 47 \%$, UK (Hall \& Rycroft, 2007) \\
\hline
\end{tabular}

Note: $\mathrm{CPS}=$ coagulase-positive Staphylococci; CNS= coagulase-negative Staphylococci. 
goats in first or second parities. McDougall et al. (2002) stated that increasing prevalence with age may be due to the increased length of exposure to pathogens in older compared to younger animals. The recent report from Megersa et al. (2010) stated that according to univariable analysis of potential risk factors, the goat with parity more than five had a significant association with having subclinical mastitis $(\mathrm{OR}=2.3, \mathrm{P}=0.028,95 \% \mathrm{CI}=1.1,4.9)$.

Udder inflammation status was found to have a significant association with the presence of CPS. Moreover results of logistic regression in the Table 3 confirmed that the udder with inflammation had a strong and significant association with and higher prevalence of CPS $[\mathrm{OR}=2.622, \mathrm{P}=0.001,95 \% \mathrm{CI}=1.487,4.623]$ compared to the normal udders. In this case, the report by Megersa et al. (2010) also in agreement with this study results, they showed that goat's udders with length more than $2 \mathrm{~cm}$ had significantly 2.2 times higher chance to get mastitis as compared to those with lenght less than $2 \mathrm{~cm}(\mathrm{OR}=$ 2.2, $\mathrm{P}=0.019,95 \% \mathrm{CI}=1.1,4.2$ ).

The data of CMT results as compared to the positively contaminated samples by indicator bacteria based on plate count method are shown in the Table 4. Despite of statistical significance, numerically the proportion of CMT positive samples which yielded bacterial growth was higher compared to CMT negative samples which yielded bacterial growth in all indicator bacteria (Table 4).

Based on this study results in Table 4, it can be stated that CMT can become cheap and handy useful tool for the dairy goat farmer to do screen testing of IMI or subclinical mastitis in dairy goats. The positive CMT result can be used as an indicator of pathogenic bacterial contamination in the milk. Therefore the farmer can easily differentiate between contaminated and uncontaminated individual milk, in order to guarantee the quality and safety of their milk production. The high quality and safety of milk production can ensure their business sustainability.

\section{CONCLUSION}

The number of bacteria in individual raw goat milk samples exceeded the maximum limit of the available

Table 3. Results of the potential risk factors evaluation

\begin{tabular}{|c|c|c|c|c|}
\hline Indicator bacteria & Factors/Level & OR & P-value & 95\% Confidence interval \\
\hline \multirow[t]{4}{*}{ Coliforms } & Breed & & & \\
\hline & - Ettawa Crossbreed (EC) & 1.000 & - & 0 \\
\hline & Saanen Crossbreed & 3.942 & 0.000 & {$[2.348,6.618]$} \\
\hline & Jawarandu (Local crossbreed) & 1.305 & 0.564 & {$[0.528,3.226]$} \\
\hline \multirow[t]{9}{*}{ CPS } & Parity & & & \\
\hline & - First & 1.000 & - & 0 \\
\hline & Second & 0.900 & 0.778 & {$[0.431,1.876]$} \\
\hline & Third & 1.853 & 0.118 & {$[0.856,4.013]$} \\
\hline & Fourth & 1.764 & 0.253 & {$[0.666,4.672]$} \\
\hline & Fifth & 6.033 & 0.050 & {$[0.999,36.455]$} \\
\hline & Udder inflammation & & & \\
\hline & · Yes & 2.622 & 0.001 & {$[1.487,4.623]$} \\
\hline & $\cdot$ No & 1.000 & - & 0 \\
\hline
\end{tabular}

Note: $\mathrm{CPS}=$ coagulase-positive Staphylococci; $\mathrm{OR}=$ odds ratio.

Table 4. Comparison between California Mastitis Test (CMT) and conventional bacteriological isolation results of indicator bacteria from udder-half milk samples

\begin{tabular}{lccccc}
\hline Indicator bacteria & CMT Results & $\mathrm{n}$ & $\mathrm{n}(+)^{*}$ & $\begin{array}{c}\text { Percent of positive } \\
\text { samples }\end{array}$ & P-value \\
\hline Coliforms & $(-)$ & 112 & 50 & 44.6 & 0.000 \\
& $(+)$ & 188 & 89 & 47.3 & 0.000 \\
CPS & $(-)$ & 112 & 30 & 26.8 & 44.1 \\
& $(+)$ & 188 & 83 & 59.8 & 0.419 \\
CNS & $(-)$ & 112 & 67 & 69.7 & \\
\end{tabular}

Note: * Positive samples based on conventional bacteriological isolation; ${ }^{* *}$ McNemar Chi-square test; CPS= coagulase-positive Staphylococci; CNS $=$ coagulase-negative Staphylococci. 
standards. Overall prevalence of the indicator bacteria from udder-half milk samples of this study were relatively higher compared to the other reports from other countries. The bacterial contamination associated mainly with the intramammary infection. More efforts and measures must be taken in order to increase sanitary and hygienic level of all components and processes within the dairy goat farms to produce safer goat milk for the consumer.

\section{REFERENCES}

Ali, Z., M. Ghulam, A. Tanvir, K. Rifatullah, N. Shabana, A. Hasib, A. F. Farooq, N. M. Muhammad, \& R. U. Abdul. 2010. Prevalence of caprine sub-clinical mastitis, its etiological agents and their sensitivity to antibiotics in indigenous breeds of Kohat, Pakistan. Pak. J. Life Soc. Sci. 8: 63-67.

Bergonier, D., R. De Cremoux, R. Rupp, G. Lagriffoul, \& X. Berthelot. 2003. Mastitis of dairy small ruminants. Vet Res 34: 689-716.

BGB1 (Bundesgesetzblatt). 2004. Milchverordnung Verordnung über Hygiene-und Qualitätsanforde-rungen an Milch und Erzeugnisse auf Milchbasis. Neugefasst durch Bek. v. 20. 7.2000 I 1178; zuletzt geändert durch Art. 5 V v. 9.11.2004 I 2791. Bundesministerium der Justiz, Bundesrepublik Deutschland, $29 \mathrm{p}$.

Boscos, C., A. Stefanakis, C. Alexopoulos, \& O. Samartzi. 1996. Prevalence of subclinical mastitis and influence of breed, parity stage of lactation and mammary bacteriological status on coulter counts and California mastitis test in milk of Saanen and autochthonous goats. Small Rumin Res 21: 139-147.

BSN (Badan Standardisasi Nasional). 1998. Susu Segar. SNI 01-3141-1998. Badan Standadisasi Nasional Jakarta.

Contreras, A., D. Sierra, A. Sanchez, J. C. Corrales, J. C. Marcoc, M. J. Paape, \& C. Gonzalo. 2007. Mastitis in small ruminants. Small Rumin. Res. 68: 145-153.

Dawson, B. \& R. G. Trapp. 2004. Basic and Clinical Biostatistics. $4^{\text {th }}$ ed. Mc Graw Hill. International Edition, $438 \mathrm{p}$.

EC (European Council). 1992. EC Directive 92/46/EEC of 16 June 1992 laying down the health rules for the production and placing on the market of raw milk, heat-treated milk and milk-based products. Luxembourg, $41 \mathrm{p}$.

FAO (Food and Agricultural Organization). 2010. FAOSTAT. http://faostat.fao.org/site/569/DesktopDefault. aspx?PageID=569\#ancor. [28 Oktober 2010].

FDA (Food and Drug Administration). 2001. Aerobic Plate Count. Bacteriological Analytical Manual Online. US FDA CFSAN. http://www.cfsan.fda.gov/ ebam/bam-3.html. [20 Agustus 2006].

Foschino, R., A. Invernizzi, R. Barucco, \& K. Stradiotto. 2002. Microbial composition, including the incidence of pathogens, of goat milk from the Bergamo region of Italy during a lactation year. J. Dairy Res. 69: 213-225.

Galal, S. 2005. Biodiversity in goats. Small Rumin. Res. 60: 75-81.

Goldberg, J. J., P. A. Murdough, A. B. Howard, P. A. Drechsler, J. W. Pankey, G. A. Ledbetter, L. L. Day, \& J. D. Day. 1994. Winter evaluation of a postmilking powdered teat dip. J Dairy Sci 77: 748-758.

Gonzalo, C., A. Ariznabarreta, J. A. Carriedo, \& F. San Primitivo. 2002. Mammary pathogens and their relationship to somatic cell count and milk yield losses in dairy ewes. J. Dairy Sci. 85: 1460-1467.

Hall, S. M. \& A. N. Rycroft. 2007. Causative organisms and somatic cell counts in subclinical intramammary infections in milking goats in the UK. Vet Rec 160: 19-22.
ISO (International Organization for Standardization). 1999. ISO 6887-1. International Standard: Microbiology of food and animal feeding stuffs - Preparation of test samples, initial suspension and decimal dilutions for microbiological examination - Part 1: General rules for the preparation of the initial suspension and decimal dilutions. ISO Geneve, $5 \mathrm{p}$.

ISO (International Organization for Standardization). 1999. ISO 6888-1. International Standard: Microbiology of food and animal feeding stuffs - horizontal method for the enumeration of coagulase-positive staphylococci (Staphylococcus aureus and other species). Part 2: Technique using Baird Parker agar medium. ISO Geneve, $11 \mathrm{p}$.

Koop, G., T. van Werven, H. J. Schuiling, \& M. Nielen. 2010. The effect of subclinical mastitis on milk yield in dairy goats. J. Dairy Sci. 93: 5809-5817.

Kyozaire, J. K., C. M. Veary, I. M. Petzer, \& E. F. Donkin. 2005. Microbiological quality of goat's milk obtained under different production systems. J. S. Afr. Vet. Assoc. 76: 69-73.

Leitner, G., U. Merin, \& N. Silanikove. 2004. Changes in milk composition as affected by subclinical mastitis in goats. J. Dairy Sci. 87:1719-1726.

Leitner, G., U. Merin, Y. Lavi, A. Egber, \& N. Silanikove. 2007. Aetiology of intramammary infection and its effect on milk composition in goat flocks. J Dairy Res 74: 186-193.

Lilenbaum, W., V. Renato, M. Luciana, G. C. Ana, C. Amanda, N. S. Guilherme, R. Leonardo, \& A.V. Silvio. 2008. Risk factors associated with leptospirosis in dairy goats under tropical conditions in Brazil. Res. in Vet. Science 84: 14-17

Little, C. L. \& J. de Louvois. 1999. Health risks associated with unpasteurized goats' and ewes' milk on retail sale in England and Wales. A PHLS Dairy Products Working Group Study. Epidemiol Infect 122: 403-408.

McDougall, S., P. Murdough, W. Pankey, C. Delaney, J. Barlow, \& D. Scruton. 2001. Relationship among somatic cell count, California mastitis test, impedance and bacteriological status of milk in goats and sheep in early lactation. Small Rumin Res 40: 245-254.

McDougall, S., W. Pankey, C. Delaney, J. Barlow, P. A. Murdough, \& D. Scruton. 2002. Prevalence and incidence of subclinical mastitis in goats and dairy ewes in Vermont, USA. Small Rumin Res 46: 115-121.

McDougall, S., K.Supré, S. De Vliegher, F. Haesebrouck, H. Hussein, L. Clausen, \& C. Prosser. 2010. Diagnosis and treatment of subclinical mastitis in early lactation in dairy goats. I. Dairy Sc. 93: 4710-4721

Megersa, B., T. Chala, A. Fufa, R. Alemayehu, M. Berhanu, \& D. Etana. 2010. Occurrence of mastitis and associated risk factors in lactating goats under pastoral management in Borana, Southern Ethiopia. Trop Anim Health Prod 42:1249-1255

Mein, G. A., F. Neijenhuis, W. F. Morgan, D. J. Reinemann, J. E. Hillerton, J. R. Baines, I. Ohnstad, M. D. Rasmussen, L. Timms, J. S. Britt, R. Farnsworth, N. Cook, \& T. Hemling. 2001. Evaluation of bovine teat condition in commercial dairy herds: 1 . Non-infectious factors. Proc. 2nd Int. Symp. on Mastitis and Milk Quality, Vancouver, BC, Canada, 347-351pp.

Morgan, F., T. Massouras, M. Barbosa, L. Roseiro, F. Ravasco, I. Kandarakis, V. Bonnin, M. Fistakoris, E. Anifantakis, G. Jaubert, \& D. Raynal-Ljutovac. 2003. Characteristics of goat milk collected from small and medium enterprises in Greece, Portugal and France. Small Rumin. Res. 47: 39-49.

Moroni, P., G. Pisoni, G. Ruffo, \& P. J. Boettcher. 2005. Risk factors for intramammary infections and relationship with somatic-cell counts in Italian dairy goats. Prev Vet Med 69: 163-173.

Ndegwa, E. N., C. M. Mulei, \& S. J. Mynyua. 2001. Prevalence of microorganism associated with udder infections in 
dairy goats on small-scale farms in Kenya. J. S. Afr. Vet. Assoc. 72: 97-98.

Oliver, S. P., B. M. Jayarao, \& R. A. Almeida. 2005. Foodborne pathogens, mastitis, milk quality and dairy food safety. Papers presented at a National Mastitis Council Annual Meeting, USA.

Oliveiraa, C. J. B, E. R. Hisrich, J. F. P. Moura, P. E. N. Givisiez, R. G. Costa, \& W. A. Gebreyes. 2011. On farm risk factors associated with goat milk quality in Northeast Brazil. Small Rumin. Res. (in press)

Petrifilm $^{\mathrm{TM}}$. 2008. Interpretation guide $3 \mathrm{M}^{\mathrm{TM}}$ Petrifilm $^{\mathrm{TM}}$ E. coli and Coliform count plates. Microbiology Products. 3M Deutschland GmbH. Germany, 10 p.

Raynal-Ljutovac, K., P. Gaborit, \& A. Lauret. 2005. The relationship between quality criteria of goat milk, its technological properties and the quality of the final products. Small Rumin. Res 60: 167-177.

Ruegg, P. L. 2002. Managing the dry period for milk quality. University of Wisconsin, Madison. p. 9.

Ruegg, P. L. 2003. Practical food safety interventions for dairy production. J. Dairy Sci. 86 (E. Suppl.): E1-E9.

Sanchez, A., A. Contreras, \& J. C. Corrales. 1999. Parity as a risk factor for caprine subclinical intramammary infection. Small Rumin Res 31: 197-201.
Shearer, J. K. \& B. Harris Jr. 2003. Mastitis in dairy goats. IFAS Extension. University of Florida, USA. p. 7.

Silanikove, N., G. Leitner, U. Merin, \& C. G. Prosser. 2010. Recent advances in exploiting goat's milk: quality, safety and production aspects. Small Rumin Res 89: 110-124

Stuhr, T. \& K. Aulrich. 2010. Intramammary infections in dairy goats: recent knowledge and indicators for detection of subclinical mastitis. Landbauforschung - vTI Agriculture and Forestry Research 4: 267-280.

Wakwoya, A., B. Molla, K. Belihu, J. Kleer, \& G. Hildebrandt. 2006. A cross sectional study on the prevalence, antimicrobial susceptibility patterns and associated bacterial pathogens of goat mastitis. Intern. J. Appl. Res. Vet. Med. 4: 169-176.

Win Episcope ${ }^{\circledR}$ Version 2.0. 2000. CLIVE: Computer-aided Learning In Veterinary Education, Learning Technology Section of the College of Medicine and Veterinary Medicine, University of Edinburgh. http://www.clive. ed.ac.uk/cliveCatalogueItem.asp?id=B6BC9009-C10F4393-A22D-48F436516AC4 [27 July 2011].

Zweifel, C., J. E. Muehlherr, M. Ring, \& R. Stephan. 2005. Influence of different factors in milk production on standard plate count of raw small ruminant's bulk-tank milk in Switzerland. Small Rumin. Res. 58: 63-70. 